Outi Hakola

\section{VALLATTOMAT NAISET \\ Naisen muuttuva paikka Orange Is the New Black -sarjassa}

Naisvankilasta kertovaa yhdysvaltalaissarja Orange Is the New Blackia on yhtäältä kiitelty monipuolisista henkilöhahmoista ja toisaalta kritisoitu rodullisuuden normativisuudesta niin tuotannon kuin vastaanotonkin puolella. Keskustelu on usein tulkinnut henkilöhahmoja staattisina representaatioina, jolloin sarjan kerronnassa tapahtuvat liukumat ovat jääneet vähemmälle huomiolle. Sarjallisuus kuitenkin määrittelee jatkuvasti uudelleen, mikä on soveliasta käytöstä naiselle ja millaisia mahdollisuuksia naisilla on, tai ei ole, rikkoa heille asetettuja sukupuolittuneita ja rodullistettuja rooleja ja rajoja. Tarkastelemalla sukupuolikuvausten prosessimaisuutta analysoin naiseuden normittumista ja näiden normien kyseenalaistamista amerikkalaisessa viihteessä ja nykykulttuurissa.

Yhdysvaltalainen naisvankilasta kertova komediallinen draamasarja Orange Is the New Black (USA 2013-) on herättänyt paljon keskustelua siinä esitettyjen naisrepresentaatioiden monipuolisuudesta. Sarjan on nähty sekä rikkovan (esim. Enck \& Morrissey 2015) että toistavan (esim. Caputi 2015; Najumi 2013) olemassa olevia luokkaan, sukupuoleen, etnisyyteen tai ihonväriin liittyviä stereotyyppisiä representaatioita. Sarjallisuus on osaltaan mahdollistanut erilaiset tulkinnat, sillä jaksosta toiseen eri henkilöhahmojen motivaatioita ja tavoitteita määritellään uusissa konteksteissa ja näkökulmissa. Prosessimaisuus mahdollistaa myös katsojien jatkuvan uudelleenasemoinnin. Tässä artikkelissa analysoin, miten sarjallisuus vaikuttaa naiseuteen liittyvien normien esittämiseen, esille tuomiseen ja haastamiseen.

Piper Chapman (Taylor Schilling), sarjan päähenkilö, on keskeinen väline sarjalle ominaiseen sukupuolittuneiden ja rodullistettujen kulttuuristen normien ja kategorioiden purkamiseen sekä seksuaalisuuden joustavuuden käsittelemiseen. Tarinan alussa tämä vaalea keskiluokkainen nainen on kihloissa Larry-nimisen miehen (Jason Biggs) kanssa. Hänen elämänsä näyttää olevan päällisin puolin järjestyksessä, kunnes hänen menneisyytensä luurangot paljastuvat. Hän on ollut mukana huumeiden salakuljetuksessa ex-tyttöystävänsä Alexin (Laura Prepon) kautta. Kun huumerinki paljastuu, 
myös Piper saa tuomion avunannosta. Hänet tuomitaan vuodeksi alhaisen turvallisuusasteen liittovaltion vankilaan, fiktiiviseen Litchfieldiin. Vankilassa Piper hyödyntää valkoisuuttaan etuoikeuksien saamiseen ja samanaikaisesti valittaa, kun muut vangit vaativat häntä tilille rodullisen epätasa-arvon kysymyksistä. Hän liikkuu uhriutumisen ja rikollisen identiteetin, valkoisten etuoikeuksien ja "taakan" sekä biseksuaalisuuden ja lesbouden välimaissa.

Hyödynnän feministisen teorian ymmärrystä kurittomista naisista, jotka eivät asetu kiltin ja näkymättömän naisen rooliin, käsitellessäni sukupuolittuneiden asenteiden ja normien haastamista sarjassa. Jade McKayn mukaan nykyfiktio on pakotettu käsittelemään naiseutta kontekstissa, jossa normit, rajoitteet ja konventiot tuottavat kuvauksia, jotka joko vahvistavat tai haastavat patriarkaalista diskurssia eli yhteiskuntajärjestystä, jossa miehillä on sukupuolensa takia enemmän kulttuurista, sosiaalista ja poliittista määrittelyvaltaa. Naisten sopeutuessa olemassa oleviin normeihin heidän naiseutensa nähdään luonnollisena ja ihannoitavana, mutta naiset, jotka ylittävät ja muokkaavat sopivan käytöksen rajoja, näyttäytyvät käsittämättöminä. (McKay 2006.) Jälkimmäinen moodi korostaa, miten rikkomalla totuttuja naiseuden esittämistapoja on mahdollista kyseenalaistaa sukupuolen luonnollisuutta ja miten toistuvilla rajanylitysten esittämisellä voidaan vähitellen tehdä erilaisista sukupuolikäsityksistä ymmärrettäviä (ks. Butler 1999).

Feministisessä tutkimusperinteessä rajoja ylittävää naiseutta on kutsuttu kurittomaksi, vallattomaksi (unruly) (Faith 2011; Rowe 1995; Bynum 1992) tai vikuroivaksi (Vänskä 2006). Tällainen uhmakkuus määrittyy toiminnassa, jossa nainen astuu normatiivisen paikkansa ulkopuolelle ja haastaa olemassa olevia sosiaalisia ja symbolisia käytänteitä esimerkiksi tavoittelemalla omaa etuaan tai olemalla seksuaalisesti aktiivinen tavoilla, jotka rikkovat hänen luokkaansa, etnisyyteensä, ihonväriinsä ja/tai sukupuoleensa liitettyjä käytösnormeja (Rowe 1995, 25-49; Bynum 1992, 33-34; Faith 2011, 1-2).

Orange Is the New Black-sarjan useat naishahmot astuvat kiltin tytön roolin ulkopuolelle ja haastavat olemassa olevia ajatuksia siitä, millainen naiseus on ihannoitavaa. Naiseuden kerronnallistamista lähestyn feministisestä ja intersektionaalisesta näkökulmasta, sillä keskityn "rodun" tai etnisyyden, iän ja luokan kysymysten kietoutumiseen sukupuolen ja seksuaalisuuden esittämiseen (Dhamoon 2011). Näen sarjallisuuden mahdollistavan monitahoista erilaisuutta, kun henkilöhahmoja kuvataan, kehitetään ja heille annetaan motivaatioita ja inhimillistäviä taustatarinoita. Käsitykset heidän normaaliudestaan tai poikkeavuudestaan, hyvyydestään tai pahuudestaan, rikollisuudestaan tai inhimillisistä erehdyksistään saavat uudenlaisia muotoja sarjallisuuden kautta. Analyysini keskittyy erityisesti kerronnallisiin ratkaisuihin, joissa kulttuurisia normeja ja kategorioita rikotaan rikollisuuden kautta irrottamalla naiset kotiympäristöstä ja tuomalla esille eri-ikäisiä, eritaustaisia ja rodullistettuja naisvartaloita sekä liukuvaa seksuaalisuutta. Ennen analyysiin siirtymistä käsittelen kerronnan tutkimusta metodisena lähtökohtanani ja tuon esille sarjallisuuden konteksteja tuotannon ja vastaanoton tasoilla.

\section{Kerronnallisuus, sarjamuotoisuus ja vaihtelevat näkökulmat}

Sarjallisuuden vaikutusta tutkin kerronnan tutkimuksen metodeilla, erityisesti kerronnan näkökulman, fokalisaation ja kerronnan luotettavuuden käsitteiden kautta. Audiovisuaalisesta mediasta on vaikea hahmottaa selkeää kertojaa. Toisinaan siksi voidaan ymmärtää oletettu kertoja, jolla on tiedossaan tarinan 
elementit, ja toisinaan tarinaa voidaan kertoa jonkun henkilön näkökulmasta. ${ }^{1}$ Orange is the New Blackin kerronta ei asetu kenenkään tietyn henkilön asemaan. Katsojalla on pääsy monien eri hahmojen maailmaan heidän kokemustensa ja muistojensa (takaumat menneisyyteen) kautta. Pääsy on kuitenkin rajattua ja katsojalle tarjotaan tiedonjyviä yksi kerrallaan. Eri hahmojen tulkinta perustuukin aina rajalliseen informaatioon, ja jatkuva vaihtaminen yhden henkilön näkökulmasta toiseen moninaistaa katseluprosessia.

Fokalisaatio on yksi tapa käsitteellistää monitahoista kerrontaa, jossa katsojan pääsyä tarinamaailmaan määritellään tai rajataan yhden tai useamman henkilöhahmon havaintojen, tunteiden ja kokemusten kautta (Horstkott 2009, 172; Niederhoff 2011). Kokevan ja näkevän subjektin lisäksi on tärkeää, kehen fokalisaatio kohdistuu (Bal 1999, 142-170). Henkilöhahmot määrittelevät itseään ja toisiaan muille vangeille ja katsojalle, mikä rajoittaa tarjotun tiedon luotettavuutta entisestään. Eri tavoin aukkoinen tieto henkilöhahmoista ja heidän taustoistaan korostaa kerronnan epäluotettavuutta ja luo mahdollisuuden representaatioiden ja niiden tulkintojen liu'uttamiselle.

Sarjan julkaiseminen suoratoistopalvelussa on osaltaan mahdollistanut Orange is the New Blackissa näkyvän television sarjamuodon kehittymisen, merkitysten liu'uttamisen ja henkilöhahmogallerian monimuotoistumisen. Sarja on Netflixin, globaalin elokuvien ja televisiosisältöjen suoratoistopalvelun, alkuperäistuotantoa. ${ }^{2}$ Suoratoistopalvelujen katsomistottumukset (binge viewing) ovat paljastaneet, että sarjoista katsotaan kerrallaan useampi jakso (keskimäärin 2-3 jaksoa/katselukerta) (Auletta 2014; Matrix 2014). Kun kokonainen tuotantokausi tulee katsottavaksi kerralla, katsojien merkityksenanto on joustavaa ja intiimiä. Merkitykset eivät ehdi kiinnittyä tiettyihin tulkintalinjoihin, vaan kokemus on avoimempi muuttuville tulkinnoille. Pitkäjänteisessä kerronnassa ei myöskään tarvitse toistaa tai ennakoida tapahtumia, mikä on korostanut käsikirjoitettua draamaa, jolla tavoitellaan intensiivistä kokemusta yhdessä katsojan kanssa.

Netflix on ollut eturintamassa mullistamassa (television) ohjelmajakelua joustavampaan suuntaan, sillä palvelun sisällöt ovat mobiileja ja katsottavissa käyttäjien aikataulujen mukaisesti. Koska tilaajat voivat itse kohdentaa kuluttamisensa, ei ohjelmistoa tarvitse suunnitella mainostajien suosimien katsojaryhmien tai katsojien maksimointiin tähtäävien ohjelmistokarttojen mukaisesti. ${ }^{3}$ (Ks. Shimpach 2015, 97-100.) Toimintamalli heijastuu myös Netflixin erilaiseen ohjelmatuotannon logiikkaan. Palvelu aloitti ohjelmatuotannon vuonna 2013 vahvistaakseen omaa profiiliaan.

Orange is the New Black on yksi palvelun ensimmäisiä sarjoja. Sarja pohjautuu Piper Kermanin omaelämänkerralliseen teokseen Orange Is the New Black: My Year in a Women's Prison (2010). Ensimmäinen tuotantokausi julkaistiin heinäkuussa 2013 ja neljäs tuotantokausi kesäkuussa 2016. Sarjaa tarjotaan katsojille "vahva naispääosa" -kategorian alla. Kategorian kautta on pyritty löytämään sarjalle omaa kohderyhmää. Netflixin tuotanto mittaakin suosiotaan käyttäjien katsojaprofiileilla, ei perinteisillä katsojaluvuilla. Netflix kerää jatkuvasti tietoa käyttäjiensä katsomistottumuksista, ja se pystyy hyödyntämään tietojaan omien sarjojensa rakentamisessa. Netflix-tuotannossa esille ovat päässeet riskialttiimmat sarjat, joissa on ollut mukana esimerkiksi valtavirtatuotannosta poikkeavaa kohdeyleisöajattelua. (Shimpach 2015, 97-100; Auletta 2014.) Netflix on tuonut uudenlaista näkyvyyttä esimerkiksi naishahmoille. ${ }^{4}$

Orange is the New Blackissa naiseuteen liittyvät kysymykset nousevat sarjan keskiöön, ja tästä syystä on tärkeää analysoida, millaista naiskuvaa sarjassa
1 Elokuvallisessa ilmaisussa, mihin suoratoistosarjatkin pitkälti perustuvat, kertoja on abstrakti elementti, joka sisältää visuaalisia ja äänellisiä ilmaisumuotoja sekä editoinnissa ja kehystämisessä tehtyjä valintoja. Toisin kuin kirjallisuudessa, elokuvakerronta ei tuota tunnistettavaa kertojaa, minkä takia elokuvatekstin ja katsojan välinen interaktio korostuu entisestään kerronnan määrittelyssä. (Horstkott 2009, 170-171, 189.)

2 Vuonna 1997 perustettu Netflix aloitti verkossa toimivana elokuvien vuokrauspalveluna ja siirtyi panostamaan suoratoistoon vuodesta 2007 alkaen.

3 Toisin kuin perinteisessä yhdysvaltalaisessa televisiotuotannossa digitaalista vallankumousta edustavan Netflixin rahoitus ei nojaa mainostuloihin, vaan rahoitusmalli on lainattu kaapelitelevision tilauspalveluajattelusta.

4 Televisiotutkija Sarah Arnold on kritisoinut Netflixin sukupuolittuneen kohderyhmäajattelun mahdollistavan miesrepresentaatioiden jatkumisen normaalin mittapuuna, johon naiseus suhtautuu toiseutena. Tällöin sisällön tärkein elementti on naiseus, ei teema tai tarina. (Arnold 2014.) Tulkinta kuitenkin sivuuttaa Orange is the New Blackin kohdalla sarjan tarkoitushakuisen naiseuden uudelleen määrittelyn moniulotteisena, ristiriitaisena ja joustavana kulttuurisena käytäntönä. 
tuotetaan. Lisäksi sarja on aiheensa puolesta poikkeuksellinen, sillä naisvankilakuvaukset eivät ole olleet Yhdysvalloissa tyypillisiä televisioinnin kohteita ja rikollisiin liittyvät tarinamaailmat ovat keskittyneet miehiin (Faith 2011, 255-256). Ainoastaan tilannekomedia Women in Prison (USA 1987-1988) on antanut tilaa naisvangeille televisioruudussa. Muun maalaisia esikuvia voidaan lisäksi etsiä sarjoista Prisoner (Australia 1979), Bad Girls (Englanti 1999-2006), Unité 9 (Kanada 2012) ja Wentworth Prison (Australia 2013-).

Orange is the New Black tyydyttää katsojien uteliaisuutta avatessaan portteja muutoin suljettuun yhteiskunnalliseen instituutioon (ks. Cecil 2015, 2-3). Esitetyillä tarinoilla on keskeinen merkitys myös yhteiskunnallisessa keskustelussa, sillä Yhdysvalloissa on maailman suurin (tilastollisesti tunnettu) vankimäärä. Vuoden 2014 aikana 2,8 \% väestöstä oli rangaistusjärjestelmän piirissä. ${ }^{5}$ Miesten osuus on moninkertainen naisiin verrattuna, mutta 2000-luvulla naisvankien määrä on ollut kasvussa ympäri maailman ja myös Yhdysvalloissa. Ilmiö on suunnannut huomion naisten rikollisuuteen ja tuomioihin, jotka ovat pitkiä siitäkin huolimatta, että suurin osa naisten tekemistä rikoksista on väkivallattomia rikoksia, kuten omaisuus- ja huumerikoksia. Naisten näkökulmat eivät saa huomiota maassa, jossa aktiivista populistista "tough on crime" -politiikkaa on tehty 1980-luvulta saakka. Koventuneet asenteet ovat jättäneet monet vangit ilman ääntä julkisissa keskusteluissa. (Barak, Leighton \& Cotton 2015; Glaze et al. 2015, 1, 19; Renzetti, Goodstein \& Miller 2006; Walmsley 2015.) Sarja pyrkiikin tuomaan normaalisti näkymättömien naisten ääniä kuuluviin.

Yhdysvaltalaista rangaistusjärjestelmää leimaa myös epätasa-arvoisuus, mikä näkyy tiettyjen ihmisryhmien yliedustuksessa vankien määrässä. Tutkimukset osoittavat, että ihmisten ihonväri, etnisyys ja yhteiskuntaluokka (koulutus- ja tulotaso) vaikuttavat tuomioiden jakamiseen. Rodullistava ja yhteiskuntaluokkien välinen epätasapaino johtuu osittain rakenteellisesta syrjinnästä, sillä muut kuin valkoiset saavat samasta rikoksesta pidempiä tuomioita. Tämä johtuu osittain tuomareiden ennakkoasenteista mutta myös syytettyjen taloudellisesta tilanteesta, eli siitä kuinka paljon heillä on varaa panostaa oikeuskuluihin, puolustusasianajajiin ja sakkoihin. (Barak, Leighton \& Cotton 2015; Walker, Spohn \& Delone 2012.)

Orange is the New Black tuo esille rakenteellisen syrjinnän kysymyksiä, joskin sarjan toteutustapa on herättänyt paljon keskustelua. Keskittyminen naiseuden käsittelyyn on otettu hyvin vastaan. Suurin osa kritiikistä kohdistuu sarjan rotupolitiikkaan, jonka voi nähdä toistavan perinteisiä rodullistavia ja luokkastereotyyppejä. Valkoisiksi tunnistettavat hahmot saavat etuoikeutettua kohtelua, kuten perhelomia tai parempia makuutiloja. Sen sijaan muilla tavoin rodullistetut hahmot edustavat kurjuutta tai väkivallan kierteitä. Nämä representaatiot toistavat ja tuovat esille rangaistusjärjestelmän ongelmia. Toisinaan sarja onnistuu ironian kautta kiinnittämään katsojan huomion tilanteen epäreiluuteen. Ongelmallista sen sijaan on, miten etuoikeutettu kohtelu ulottuu katsojien puhuttelutapoihin. Huolimatta siitä, että sarja esittelee laajan joukon eri taustaisia naisia, yleisöksi oletetaan valkoiseksi tunnistettava (tai siihen samaistuva) valtavirta.

Oletus kohdeyleisöstä näkyy päähenkilöön, Piperiin, liittyvissä kerronnallisissa ratkaisuissa. Piperin joutumista vankilaan yksittäisen nuoruuden erehdyksen takia on helppo pitää kohtuuttomana rangaistuksena. Ensimmäisissä jaksoissa hän joutuu kohtamaan myös vallankäyttöä sekä sosiaalisessa että seksuaalisessa mielessä muiden vankien taholta. Loukattuaan keittiön toiminnasta vastaavaa venäläistaustaista Galina "Red" Reznikovia (Kate
5 Yhdysvaltain erityinen suhde vankilatuomioihin korostuu kansainvälisessä vertailussa. Vuonna 2015 vangitsemisaste (henkilöt / 100000 asukasta) oli Yhdysvalloissa 698, Englannissa 148, Kanadassa 106 ja Suomessa 57. Naisvankien määrä vaihtelee $2 \%$ :n ja 9 $\%$ :n välillä kokonaisvankimäärästä, ja asteluku on Yhdysvalloissa 65, Englannissa 7 , Kanadassa 12 ja Suomessa 4. (Walmsley 2016; Walmsley 2015.) 


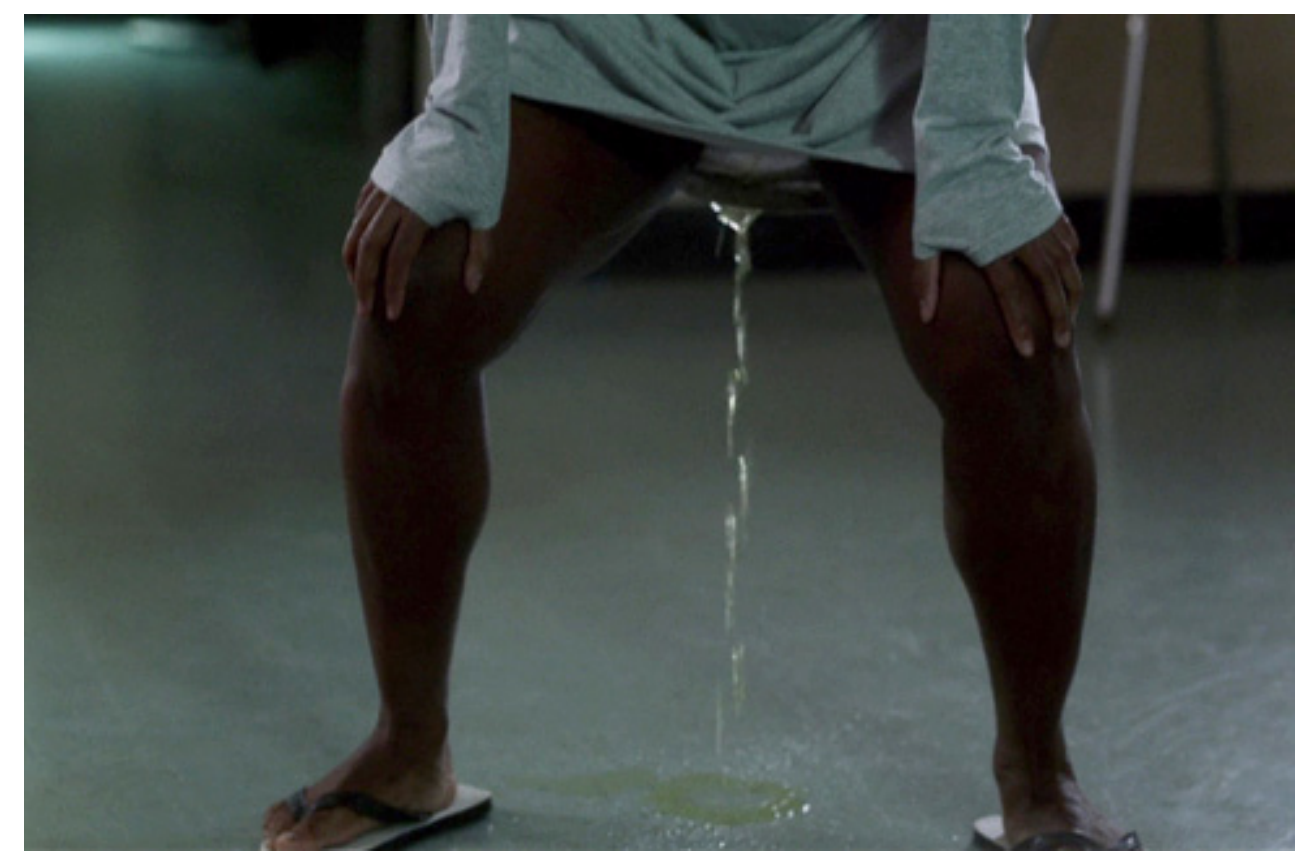

Piperin torjuttua Suzannen ("Crazy Eyes") lähestymisyritykset Suzanne kostaa virtsaamalla uhmakkaasti Piperin vuoteen edustalle keskellä yötä. Kuva: kuvakaappaus K1:J3.

Mulgrew) Piper pakotetaan nälkäkuurille. Samaan aikaan tummaihoinen "Crazy Eyes" Suzanne (Uzo Aduba) alkaa käyttäytyä aggressiivisesti Piperin torjuttua hänen romanttiset lähestymisyrityksensä (K1:J2 "Tit Punch" \& K1:J3 "Lesbian Request Denied"). Kerronnallinen ratkaisu kumpuaa stereotyyppisistä naisvankikuvauksista, jotka keskittyvät valkoiseen keskushahmoon, joka on joutunut enemmän tai vähemmän vahingossa vankilaan, jossa hän joutuu kohtamaan ja/tai todistamaan väkivaltaa ja väärinkäytöksiä sekä sadististen vankilatyöntekijöiden että aggressiivisten ja usein tummaihoisten vankien taholta (Faith 2011, 258-259).

Jenji Kohan, sarjan luoja, on selittänyt avausratkaisuaan vertauksella, jonka mukaan hän käyttää Piperia "Troijan hevosena" (Caputi 2015, 1132). Piper on helposti tunnistettava valkoinen naapurintyttö, joka mahdollistaa pääsyn näkymättömien ja marginalisoitujen - mustien, latinojen, lesbojen, transsukupuolisten, iäkkäiden, mielisairaiden ja rikollisten - naisten maailmaan. Kerronnallinen ratkaisu osoittaa, että sarjan tuotannollisissa ja vastaanottoon liittyvissä strategioissa toistuu oletus valkoisuudesta sosiaalisena normina ja normaalina.

Sarjaa kritisoineet nostavatkin esille, että Troijan hevonen -ratkaisu toistaa vanhentuneita rodullistavia kerrontamalleja, joiden mukaan ei ole riittävän kiinnostavaa, että eritaustaiset naiset kertoisivat itse omat tarinansa. Ratkaisun on nähty vahvistavan kulttuurisen imperialismin historiallisia malleja, joissa hallitseva ryhmä esitetään normina, johon muut vertautuvat. (Najumi 2013; The Feminist Griote 19.8.2013; Caputi 2015; Shackelford 2016.) Moninaiselle katsojakunnalle jää toki mahdollisuus kurittomaan tai vallattomaan vastakarvaan lukemiseen, jolla voidaan poliittisesti vastustaa samaistumista normaaliutta edustavan henkilöhahmon katseeseen (Mulvey 1986; Vänskä 2006, 16-17). Moninaisuuden tarjoaminen alusta saakka olisi kuitenkin ollut tuore kerronnallinen näkökulma. 
Sarjaa on myös kiitelty rodullisten ja seksuaalisten representaatioiden monipuolisuudesta, jolloin huomiota on kohdistettu sarjan etenemiseen, ei sen alkuasetelmiin. Sarjan edistymisen myötä Piperin hahmo saa uusia ulottuvuuksia, joissa ei vahvisteta ajatusta sankarillisesta katumus- ja selviytymistarinasta. Neljännen kauden alkuun mennessä Piper on jopa ylpeä "gangsta-asenteestaan". Yhtä lailla alussa yksiulotteisen aggressiivisiksi kuvatut naiset saavat enemmän ääntä ja tilaa kerronnassa.

Suzanne Enck ja Megan Morrissey (2015) näkevät Piperin edustavan valkoisen etuoikeuden purkamista. He argumentoivat, että yleisön samaistuessa Piperiin, joka yrittää opetella tuntemaan muita naisia, yleisö alkaa sympatisoida eritaustaisia naisia ja tunnistaa rodullistavaa ja luokkaperusteista syrjintää, joka on tyypillistä Yhdysvaltojen oikeus- ja rangaistusjärjestelmälle. Argumentti tulee toistaneeksi oletuksen, että katsojien olisi lähtökohtaisesti vaikea samaistua muihin kuin "normaaliutta" edustaviin hahmoihin. Sen sijaan heidän näkemyksensä, jonka mukaan sarjan komediallinen kehystäminen toimii välineenä dekonstruktioprosessissa, on huomion arvoinen. Kehystäminen korostaa Piperia erehtyneenä, joskaan ei lähtökohtaisesti pahana hahmona. Jakso jakson jälkeen samaa kehystämistä käytetään myös muiden naisten kuvaukseen, jolloin heistäkin tulee ihmisiä, jotka tekivät virheitä yhteiskuntajärjestelmässä, joka on taipuvainen näkemään heidät rikollisina tai pahantahtoisina. (Enck \& Morrissey 2015.) Tällä tavoin jatkuvajuoninen sarja voi tarjota muuttuvia näkökulmia ja katsoja-asemia yleisöilleen. Katsojien ei ole myöskään pakko kiinnittyä Piperiin, jonka edustamat arvot tulevat nopeasti kyseenalaistetuksi, vaan sarjalla on muitakin samaistumiskohteita.

Vaikka rodullistetut hahmot muodostavat enemmistön kurittomista naisista ja vaikka heidän tarinansa saavat näkyvyyttä, sarjan myöhempiäkin vaiheita on kritisoitu perinteisestä kohderyhmäajattelusta. Asleigh Shackelford kuvailee sarjaa valkopestynä viihteenä, jossa rodullistettujen hahmojen kärsimys toimii sosiaalipornona kohdeyleisölle. Hän näkee sarjan tuotannollisten ja katsojuuden etiikkaan liittyvien kysymysten jopa kärjistyvän sarjan kuluessa: erityisesti neljännellä tuotantokaudella kuvaukset valkoisten etuoikeuksista ja muiden vankien kärsimyksestä polarisoituvat. (Shackelford 2016.) Muun muassa Judy King (Blair Brown), jonka hahmo pohjautuu julkkiskokki Martha Stewartiin, saa oman sellin, parempaa ruokaa ja luksustuotteita. Sen sijaan ylimääräisiä ja kopeloivia ruumiintarkistuksia kohdistetaan erityisesti latinoihin. Yhtäältä ratkaisu tekee näkyväksi Yhdysvalloissa yleistä rodullista profilointia, mutta toisaalta se hakee tunnereaktioita kurjuuden kokemuksia hyväksi käyttäen. Rodullistettujen naisten kurjuudella herkuttelu populaarikulttuurissa on ollut merkittävä keskusteluaihe muun muassa "musta feminismi" -suuntauksessa (Black Feminism), joka on nostanut esille seksismin, luokan, sukupuoli-identiteetin ja rodullisuuden intersektionaalisia ulottuvuuksia (hooks 1992; Collins 2009).

Vaikka sarjamaisuus onkin siis lieventänyt kerronnan alkulähtökohtien ongelmallisuutta laajentamalla kerrontaa pois Piperin kokemuksista, on rodullisuuden ja naiseuden intersektionaalinen käsittely koettu haasteelliseksi. Orange Is the New Blackin herättämä keskustelu tuo esille, miten kerronnassa eri näkökulmien välillä vaihteleva fokalisaatio mahdollistaa moninaisten ja keskenään ristiitaisten näkökulmien rakentumisen ja näkyväksi tuomisen (ks. Bal 1999, 142-170). Kritiikki siitä, että sarja olettaa itselleen valkoisen yleisön, on tärkeä huomioida, sillä kerronnan näkökulma yhdistyy aina kysymykseen empatiasta: fokalisaatio ehdottaa, millaisiin näkökulmiin, tunteisiin tai jopa kokonaisiin maailmankuviin katsojan olisi mahdollista samaistua. Niinpä 
kerronnan rakenteiden ja kulttuuristen kontekstien analyysi on välttämätöntä: onko eroja, keiden tarinat ansaitsevat tulla kerrotuksi ja millaisia tunteita ja asenteita sarjassa liitetään eri naisvankien representaatioihin. Aloitan analyysin rikollisuuden ja vankilayhteisön käsittelyllä ja jatkan tästä ruumiillisuuden merkitysten pohdintaan.

\section{Kurittomuus rikollisuutena}

Naisten kurittomuuden määrittely on sopivan käytöksen rajojen pohtimista. Rikollisuus on yksi tapa rikkoa yhteiskunnan käytösnormeja, ja muun muassa oikeusistuimet ovat määritelleet naiseudelle sopivan käytöksen rajoja sekä uhrien että rikosten tekijöiden profiloinnin kautta (Faith 2011; Bynum 1992). Orange Is the New Blackin kurittomuuden kuvauksia voidaan tarkastella kysymällä, miksi naiset ovat ylipäänsä joutuneet vankilaan. Rangaistus ei olekaan tarinan loppu, kuten rikos- tai toimintasarjoissa, vaan uuden tarinan alku. Hahmot "syntyvät uudelleen", kun heidät sijoitetaan vankilan suljettuun instituutioon (Jarvis 2013, 154). Orange Is the New Black keskittyy vankilaelämään, esimerkiksi vankilayhteisöön sopeutumisen, eristyksen, seksuaalisuuden, seksin, masennuksen, addiktioiden ja väkivallan kokemuksiin. ${ }^{6}$ Vankilan tapahtumien ohella keskeisessä roolissa toimivat myös taustatarinat ja takaumat, joissa avataan hahmojen päätymistä vankilaan.

Taustarinat inhimillistävät hahmoja, selittävät heidän motiivejaan ja toiveitaan sekä liittävät heidän tarinansa johonkin yhteiskunnalliseen ja kulttuuriseen taustaan. Taustatarinoiden jakautuminen noudattelee amerikkalaisten vankiloiden keskimääräistä väestörakennetta, sillä takaumista noin $50 \%$ käsittelee valkoisiksi tunnistettavia hahmoja, $24 \%$ mustaihoisia, 21 \% latinoita ja 5 \% muita. ${ }^{7}$ Takaumien käsittelyssä ei ole suuria määrällisiä tai sisällöllisiä eroja, joskin latinoihin keskittyvät tarinat korostuvat vasta sarjan neljännellä tuotantokaudella. Sisällöllisesti taustatarinat kehittyvät uhriutumisesta kohti moninaisempaa ymmärrystä naisten rikollisuudesta.

Ensimmäisen tuotantokauden alussa naisten rikoksia selitetään joko inhimillisinä erehdyksinä tai moraalisesti oikeutettuna, joskaan ei laillisena käytöksenä. Hyväksynnän ja kuulumisen tarve sekä epäoikeudenmukaisuuden kokemukset korostuvat tarinamalleissa, joissa naisrikollisia mystifioidaan luomalla rikollisuuden ja uhriutumisen välille vahva kytkös (ks. Faith 2011, 13). Esimerkiksi venäläistä mafiapomo Galina "Red" Reznikovaa (Kate Mulgrew) esitellään hänen perheravintolansa kautta. Ravintola toimii kohtauspaikkana venäläiselle mafialle, johon Redin puoliso pyrkii pitämään hyvät välit. Samoin Red yrittää tutustua mafiamiesten vaimoihin, jotka eivät toivota Rediä tervetulleeksi. Red leimataan moukkamaiseksi ja jätetään ryhmän ulkopuolelle. Loukattuaan yhtä vaimoista Red ja hänen miehensä joutuvat luovuttamaan ravintolansa tiloja laittomiin toimintoihin. Ensivaikutelman mukaan Red olisi ajautunut rikolliseen maailmaan kuulumisen tarpeensa takia. (K1:J2 "Tit Punch".)

Tarina, jossa nainen etsii hyväksyntää, toistuu usein. Sophia (Laverne Cox), transsukupuolinen nainen, on tuomittu luottokorttirikoksesta, jolla hän rahoitti sukupuolenkorjauksen voidakseen toteuttaa omaa identiteettiään (K1:J3 "Lesbian Request Denied"). Watson (Vicky Jeudy), nuori juoksijalahjakkuus, asuu köyhällä mustien asuinalueella, jossa harvalla nuorella on mahdollisuuksia edetä pitkälle elämässään. Häntä kannustetaan hyödyntämään urheilullisuuttaan reittinä toisenlaiseen elämään, mutta samaan aikaan Watson kokee
6 Samanlaisia teemoja on käsitelty myös sarjan brittiläisessä esikuvassa, Bad Girls -sarjassa. Näitä teemoja on laajasti analysoinut muun muassa Didi Herman (2013).

7 Vuonna 2014 Yhdysvalloissa naisvangeista $50 \%$ tilastoitiin valkoisiksi, $21 \%$ mustiksi, $17 \%$ latinoiksi ja $12 \%$ muiksi (Carson 2015). 
eristäytyvänsä ikätovereistaan. Sosiaalista hyväksyntää etsiessään hän päätyy mukaan rikolliseen toimintaan. (K1:J7 "Blood Donut".) Rikoksia kuvataan usein inhimillisinä erehdyksinä, joissa nainen näyttäytyy harhaanjohdettuna uhrina, jota on motivoinut halu kuulua, ei halu olla rikollinen. Kaipaus on tunnistettava tunne, joka voi synnyttää sympatian tai empatian kokemuksia katsojassa.

Toinen tarinamalli perustuu epäoikeudenmukaisuuden kokemukseen. Tällöinkin rikoksiin voi liittyä erehtymisen ulottuvuus, joka yhdistetään moraaliseen oikeuteen kostaa tai tavoitella parempaa elämää. Tarinamalliin kuuluu myös epäitsekkyys, kun nainen on pyrkinyt suojelemaan heikommassa asemassa olevia. Miss Claudette (Michelle Hurst), lapsityövoiman kautta Yhdysvaltoihin tullut nainen, tappaa miehen, joka on pahoinpidellyt hänen alaisuudessaan työskentelevän siivoojatytön (K1:J4 "Imaginary Enemies"). Kotiväkivallan uhri Gloria Mendoza (Selenis Leyva) syyllistyy petokseen kerätessään rahaa, jotta voisi viedä lapsensa turvaan (K2:J5 "Low Self Esteem City"). Vaikka naiset ottavat vastuun teoistaan, heidän taustatarinansa saavat katsojan helposti puolelleen.

Katsojasta rikokset voivat vaikuttaa ymmärrettäviltä tai oikeutetuilta, sillä katsomiskokemusta määrittelevät myös populaarikulttuurin perinteet, jossa silmä silmästä on tuttu kaava muista rikoksiin keskittyvistä genreistä. Amerikkalaisissa tarinoissa oikeutta on jaettu (usein ilman rikosoikeudellisia seuraamuksia) nopeasti ja automaattisesti erityisesti tilanteissa, joissa oikeudenmukaisuus on kärsinyt korruptoituneessa tai epätasa-arvoisessa sosiaalisessa järjestelmässä. (Cawelti 1975, 529-534; Welsh, Fleming \& Dowler 2011.) Tässä suhteessa rangaistuksiin liittyvät tarinat luovat moninaisemman kuvan sosiaalisesta oikeuskäsityksestä (Cecil 2015, 1).

Myöskään Orange is the New Black ei jättäydy mystifioidun kuvan varaan, vaan sarjan kehittyessä asetelmaa aktiivisesti puretaan ja uudet näkökulmat kääntävät aiempia tulkintoja päälaelleen. Red, joka epäonnistui ystävystymään venäläisnaisten kanssa, huomaa tulevansa toimeen heidän miestensä kanssa, ja hänestä tulee yksi johtajista mafian sisäpiiriin (K1:J8 "Moscow Mule"). Myös vankilayhteisössä hän on ottanut valtaapitävän naisen roolin, josta hän on ylpeä. Piperista puolestaan kuoriutuu itsekäs ja etuoikeutettu nainen, jonka rikollisuus alkaa selittyä kyllästymisellä ja kokeilunhalulla. Vaikka Piper ylläpitää ylemmyydentuntoaan ja vääristynyttä kuvaa "hyvänä ihmisenä" olemisesta, hänkin tunnustaa tehneensä huonoja valintoja ja olevansa vankilassa omasta syystään (K1:J6 "WAC Pack"). Tämä on merkki kasvavasta tietoisuudesta mutta ei katumuksesta. Hetki edustaa myös sarjan tyypillistä kerronnallista ratkaisua, jossa naiset siirretään passiivisesta uhrin asemasta aktiiviseksi toimijaksi, joka on vastuussa valinnoistaan.

Takaumat siten moninaistavat tulkintamahdollisuuksia. Esimerkiksi Tiffany "Pennsatucky" Doggettin (Taryn Manning) tarinassa jokainen takauma tuo uutta tietoa hahmon motivaatiosta, mutta takaumat haastavat, eivät vahvista olemassa olevaa kuvaa hänestä. Ensimmäisellä tuotantokaudella Pennsatuckysta luodaan hirviömäistä kuvaa. Hän on vankilassa tapettuaan aborttiklinikan työntekijän. Hänen takaumansa ja käytöksensä vankilassa luovat kuvaa itsekkäästä, impulsiivisesta ja mielenterveydeltään epätasapainoisesta naisesta, joka ei kaihda väkivaltaan tarttumista (K1:J2 "Fool Me Once"). Kolmannella tuotantokaudella paljastuu seksuaalisen hyväksikäytön tausta, joka inhimillistää Tiffanya (K3:J10 "A Tittin' and a Hairin"'). Carrie "Big Boo" Black (Lea DeLaria), jota Tiffany aluksi julkisesti vihasi tämän lesbouden takia, opettaa Tiffanya arvostamaan naiseuttaan ja vaatimaan ar- 
vostusta myös muilta. Uhrin asema paljastetaan vasta, kun Tiffany on valmis astumaan tämän roolin ulkopuolelle.

Sarjalle ovat ominaisia liukuvat tulkinnat hahmoista ja lineaarisen kerrontatavan purkaminen: yhtäältä uhreista tehdään toimijoita ja toisaalta aggressiivisista hahmoista tehdään samaistuttavia. Eva Krainitzki on huomioinut, miten Orange Is the New Blackin ei-lineaarinen kerronta yhdistää menneisyyttä ja nykyisyyttä tavoilla, jotka luovat intersektionaalisia ja liukuvia identiteettejä. Sarja ei tarjoa pelkästään monenlaisia hahmoja, vaan yhdenkin hahmon kohdalla iän, sukupuolen, seksuaalisuuden ja rodullisuuden kokemukset muuttuvat jatkuvasti. Tilan ja ajan vapaa manipulointi purkaa stereotyyppejä ja luo monikerroksisuutta hahmoihin. (Krainitzki 2016, 209-215.)

Sarjassa ei keskustella, ovatko nämä naiset rikkoneet lakia, katuvatko he tekojaan, etsivätkö he anteeksiantoa tai pyrkivätkö he minkäänlaiseen parannukseen. Sen sijaan heidän tarinansa kertovat selviytymisestä ja omanarvon säilyttämisestä. Omanarvontunteen merkitys näkyy niin transsukupuolisen Sophian tarinassa kuin Big Boon hahmossa; Big Boo kieltäytyy piilottamasta butch-lesbon identiteettiään ja olemasta julkisesti näkymätön, vaikka asenne johtaa aggressiivisiin yhteydenottoihin (K3: J4 " Finger in the Dyke").

Orange Is the New Blackin naiset ovat jopa ylpeitä valinnoistaan, jotka ovat olleet yhteiskunnan silmissä vääriä. Pankkiryöstäjä Rosa (Barbara Rosenblat) ei vieritä syyllisyyttään muille vaan muistelee, miten ryöstely innosti häntä ja miten hän rakasti rahan tuoksua. Vankilan ulkopuolella tapahtuvien syöpähoitojen aikana hän viihdyttää nuorta miespotilasta innostavilla tarinoillaan (K2:J8 "Appropriately Sized Pots"). Vaikka Rosa ei kadu rikollista elämäänsä, hänestä ei rakenneta pahaa ihmistä. Hänen hyvyytensä tai pahuutensa ei ole sidottu siihen, onko hän kykeneväinen seuraamaan lakia, vaan kerronta pai-

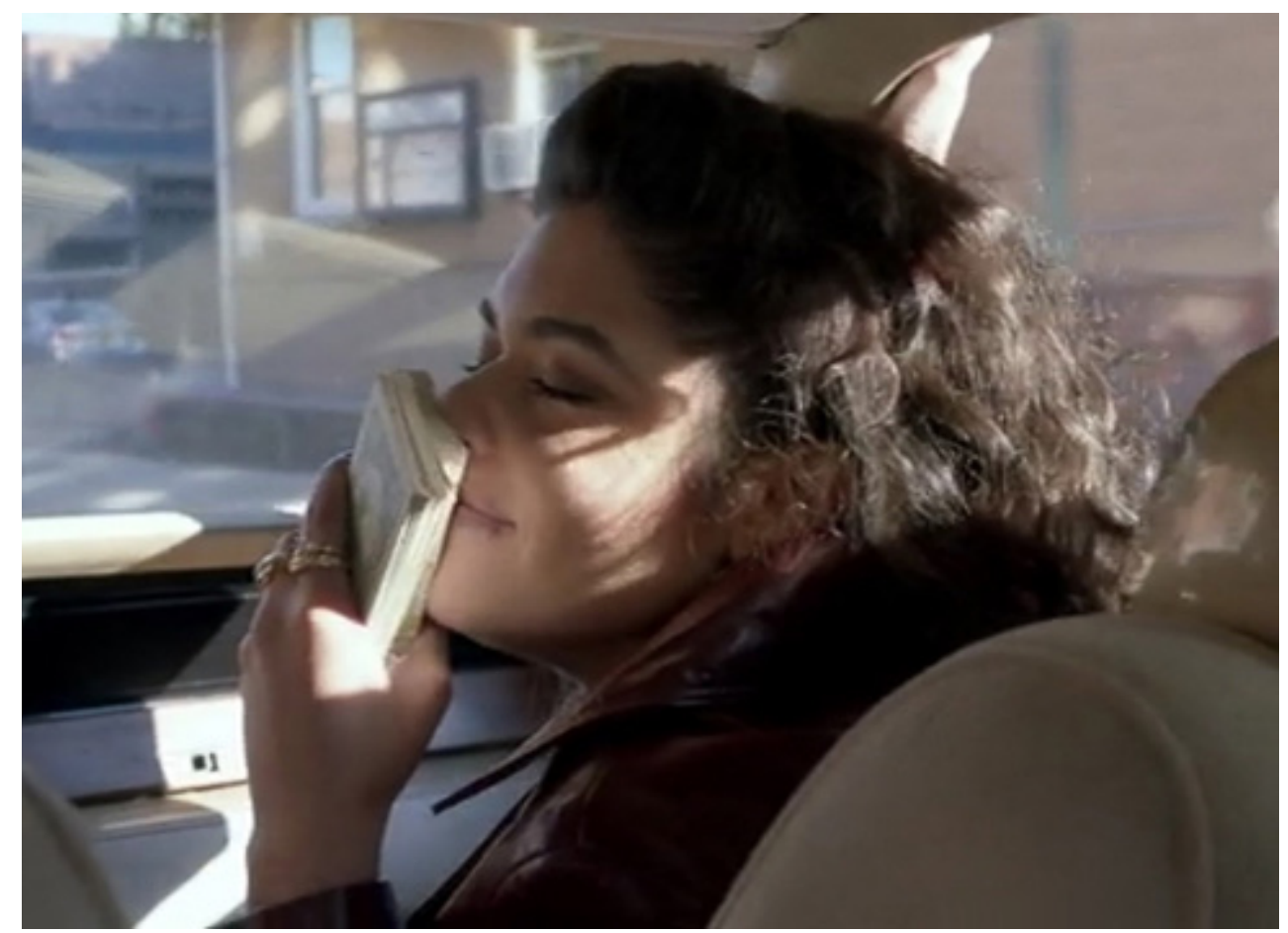

Pankkiryöstäjä Rosa huumaantuu varastetun rahan tuoksusta. Kuva: kuvakaappaus K2:J8. 
nottaa hänen kykyään toteuttaa itseään ja unelmiaan. Hänen arvonsa naisena määritellään sarjan kerronnassa hänen itsekunnioituksensa kautta.

Litchfieldin vankilan kurittomat naiset ovat ylpeitä ollessaan oman tarinansa päähenkilöitä, ollessaan itsekkäitä ja vaatiessaan näkyvyyttä. Rowen mukaan kurittomuus näyttäytyykin sosiaalisena toimintana, jossa nainen asettaa itsensä spektaakkeliksi julkisessa tilassa ja tekee siten itsestään aktiivisen toimijan, näkymättömästä näkyvän. Nainen voi rikkoa sääntöjä olemalla liian kapinallinen (esim. rikollisen toiminnan kautta), jolloin naisesta muodostuu ambivalentti, jopa uhkaava hahmo, joka horjuttaa sosiaalisia normeja. (Rowe 1995, 25-49.) Orange Is the New Blackin kurittomuuden representaatiot ovat läsnä myös epätoivoisissa kohtaloissa. Esimerkiksi Gloria Mendoza ei suostunut sopeutumaan väkivaltaiseen perhetilanteeseen, vaan hän oli valmis rikkomaan yhteiskunnan normeja ja sääntöjä päästäkseen pois epäterveestä parisuhteesta. Hänestä tulee metaforisesti kuriton nainen, joka ei asetu häneltä odotettuun rooliin eikä toimi yhteiskunnan odottamalla tavalla.

\section{Kurittomuus kodin hengettären vastakohtana}

Taustatarinoiden ohella kurittomuutta määrittelee vankilaelämä. Tavat, joilla naisten käytös esitetään vankilakuvauksissa, viestittävät, millaista on sallittu naisellinen käytös ja millainen käytös on tuomittavaa (Cecil 2015, 16). Orange Is the New Blackissa vankilan säännötja esimerkiksi sosiaalityöntekijä Sam Healyn (Michael J. Harney) antamat ohjenuorat luovat kuvan sallitusta naiseudesta, jota määrittävät arkirutiinit, työnteko, hiljaiselo ja seksuaalisuuden tukahduttaminen. Healyn mukaan vankien tulisi muistaa, että heidän todellinen elämänsä on vankilan ulkopuolella, ei sen sisällä.

Lähtökohtaisesti naisvangit eivät kuitenkaan vain odota todellisen elämän alkamista, vaan vankilayhteisöstä tulee heille elämänvaihe, josta etsitään yhtä lailla merkityksiä kuin vankilan ulkopuolisistakin suhteista. Brittiläisiä draamoja tutkineen Vicky Ballin mukaan naisyhteisökuvaukset luovat vaihtoehtoisia elämäntyylejä naisille. Tyypillisimmät televisiomaailmassa naisille sallitut/naisilta oletetut roolit ovat puolison ja äidin roolit. Uranaiseus poikkeaa tästä tuomalla feminiinisyyttä tai jopa naismaskuliinisuutta patriarkaalisiin instituutioihin, mutta vieläkin vaihtoehtoisempi ilmaisu on yhteisö, kuten naisvankila, joissa keskiöön nostetaan naisten yhteisöllinen valta ja naisten keskinäiset suhteet. (Ball 2013, 246.)

Samoin Orange Is the New Blackissa naiseutta ei arvioida ensisijaisesti äitiyden, vaimon tai tyttöystävän roolin kautta, vaan naisvangit näyttäytyvät kurittomina osittain juuri sen takia, etteivät he ole käytettävissä ja saavutettavissa hoitaakseen "naiselliset tehtävänsä". Kunnollisen naiseuden teemaa kyseenalaistetaan muun muassa Lorna Morellon (Yael Stone) hahmolla. Lorna esitetään aluksi häitään suunnittelevana, feminiinistä ulkonäköään vaalivana herttaisena naisena. Jatkuvan kerronnan myötä hänen suhteensa paljastuu kuvitelmaksi ja hänen suhtautumisensa romanttisiin kiinnostuksen kohteisiin aggressiivisen vainoharhaiseksi. Perinteisen perhe-elämän ideaali katoaa tavoittamattomaksi harhaksi. Tällä tavoin Lornakin edustaa kurittomuutta, jossa hoivaamisen sijasta naiset ovat astuneet "maskuliiniselle" alueelle (rikollisen) omaneduntavoittelun kautta.

Karlene Faithin mukaan kurittomuus kertookin enemmän yhteiskunnan järjestäytymisestä kuin naisten elämästä. Yhteiskunnan normit usein ylläpitävät perinteisiä valtasuhteita, ja hylätessään patriarkaalisen auktoriteetin ja 
toimimalla kontrolloimattomasti ja ennalta-arvaamattomasti naisen suurin rikos on kykenemättömyys keskiluokkaisen naiseuden kuvaan. Siten kuriton nainen on porvarillisen mielikuvituksen ja patriarkaalisen yhteiskunnan luoma sosiaalinen konstruktio, joka uudelleen määrittelee sukupuoleensa liittyviä normeja. (Faith 2011, 1-2.)

Vaikka vankilaan joutumisen voi nähdä kurinpalautuksena hyväksytyn käytöksen ulkopuolelle astumisesta, Orange Is the New Black korostaa, etteivät kaikki naiset edes toivo voivansa astua "hyvän" naisen rooliin, josta vankila voi tarjota jopa pakomahdollisuutta. Sarjan alussa Piper edustaa perinteistä heteroparisuhdetta, mutta vankilassa hän pettää sulhastaan ex-tyttöystävänsä ja myöhemmin tyttöystäväänsä toisen vangin kanssa. Vakiintumisen sijasta Piper haluaa jatkaa seikkailujaan heteronormatiivisen ja monogaamisen parisuhdeinstituution ulkopuolella, joskin yksinäisyyden hetkellä Piper ehdottaa ex-sulhaselleen yhteen paluuta. Larry epäilee osuvasti, että Piper katuisi päätöstään vankilasta vapautumisen jälkeen (K2:J6"You Also Have a Pizza").

Litchfieldin vankilan naisyhteisössä perinteiset perhe- ja sukupuoliroolit menettävät merkityksensä. Vaikka perheet ovat osa naisten tarinoita, vankilan ulkopuolisten suhteiden kuvaus vähenee tuotantokaudesta toiseen. Sen sijaan vankilan sisäiset "perheet" ja roolit luodaan hahmojen muihin ominaisuuksiin nojaten. Naiset hoitavat vankilan kunnostustöitä sähköhuollosta pyykinpesuun, eikä työtehtäviä sukupuoliteta. Lisäksi toimijuutta rakennetaan kiellettyjen aktiviteettien, kuten mustan pörssin, käytettyjen pikkuhousujen myynnin ja huumeiden salakuljetuksen, kautta. Vaikka Litchfield on naisten maailma, se ei ole passiivinen tai kodillinen.

Orange Is the New Black muistuttaa Brian Jarvisin huomiota HBO:n miesvankilasarja Ozista (USA 1997-2003). Jarvis näkee miesten vankilamaailman loputtomana maskuliinisuuksien esittämisenä, joka pakenee ulkopuolisen, feminiinisen alueen kodillisuutta ja kuluttamisen luomaa "ansaa" miehille ja mieskatsojille. (Jarvis 2013, 164-167.) Tekemällä saman naishahmojen kautta Orange is the New Black purkaa mielikuvaa miesten ja naisten tiloista ja paikoista. Sarja irrottaa naiset kodin piiristä ja niistä rooleista, joita yhteiskunta tuntuu tarjoavan naisille, ja sen sijaan luo naisista aktiivisia omaneduntavoittelijoita ja julkisen tunnustuksen vaatijoita. Naiset rakentavat toimijuuttaan myös keskinäisissä (seksuaalisissa) suhteissaan, joissa miehillä on marginaalinen rooli. Seuraavaksi siirrynkin käsittelemään ruumiillisuuden kurittomia elementtejä.

\section{Kuriton ruumiillisuus}

Vankilayhteisöjen esittämisessä rakennetaan sijaissuhteita, jotka perustuvat jaettuun kokemukseen ja intiimiin kanssakäymiseen, mutta jolla on vain vähän tekemistä vankilan ulkopuolisen maailman kanssa. Jarvis kategorisoi televisioidun vankilayhteisön $(O z)$ viestinnän kahteen toimintamalliin. Ensinnäkin yhteisöä muotoilee juoruilu, joka korostaa tiedon merkitystä yhteisön jäsenyydessä. Toiseksi korostuu ruumilllinen viestintä, jolla kompensoidaan vangin kokemaa kontrollin puutetta. Ruumiillisuus on osa-alue, jota vankikin voi edelleen osin hallita, mikä näkyy kuntoilun, seksuaalisuuden, väkivallan ja seksuaalisen väkivallan näkymisenä kerronnassa. (Jarvis 2013, 159-164.)

Molemmat viestintämuodot painottuvat myös Orange Is the New Black -sarjan kuvitteellisessa vankiyhteisössä. Naiset ovat jakautuneet ryhmittymiin perustuen esimerkiksi ihonväriin, etnisyyteen, uskonnollisuuteen ja/tai ikään. Ryhmät reagoivat vankilaelämän tapahtumiin eri tavoin ja puolustavat omiaan 
mutta tarvittaessa liittoutuvat yhteen henkilökunnan väärinkäytöksiä vastaan. Ensimmäisellä tuotantokaudella ryhmäytyminen nostetaan keskusteluun, kun sosiaalityöntekijä Sam Healy (Michael J. Harney) on perustamassa vankien neuvottelukuntaa. Piperia opastetaan, miten kukin voi äänestää vain oman rodullisen ryhmänsä ("white, black, hispanic, golden girls and others") sisällä. Nicky Nichols (Natasha Lyonne) auttaa katsojaa asennoitumaan tilanteeseen ironialla: "Just pretend it's the 1950s. It makes it easier to understand." (K1: J6 "WAC Pack".) Ryhmittymät näkyvät kaikilla tuotantokausilla, mutta sarjan edetessä ironinen ja komediallinen kehystäminen vähenee ja painopiste siirtyy jännitteiden kasvattamiseen. Neljännellä tuotantokaudella vankilan yksityistämisen seurauksena vankimäärä kaksinkertaistuu ja ryhmittymien välinen valtapeli kärjistyy rasistiseen nimittelyyn, väkivallalla uhkaamiseen ja jopa väkivallan käyttöön (esim. K4:J2 "Powersuit"). Samalla ryhmittymien välisten rajojen ylittyminen vähenee ja jää lähinnä rotujen välisten romanssien ja seksuaalisuhteiden varaan.

Väkivalta ei kuitenkaan korostu sarjassa samassa määrin kuin monissa miesvankiladraamoissa, joissa tarinakaaret ovat liittyneet manipulointiin, negatiiviseen kuvaukseen ja väkivaltaisiin valtapeleihin (Cecil 2015, 16). Sen sijaan Orange is the New Blackissa väkivallan kierrettä harvoin käytetään haastamaan naisen normalisoitua paikkaa. Kurittomuutta on rakennettu naisruumiiden esille tuomisella, arkisella toiminnalla, läsnäololla ja seksuaalisuudella, sillä kuriton nainen voi olla liian hauska tai äänekäs, hän voi luoda itsestään ylitsevuotavan ruumiillisen spektaakkelin olemalla liian lihava tai vanha, tai hän voi ilmaista seksuaalisuuttaan kontrolloimattomasti (Rowe 1995, 25-49, Gordon 2004, 1; Miller 2013, 368).

Ruumiillisuuden korostuminen näkyy sarjan tunnuskappaleessa, jonka aikana kuvataan vuorotellen naisten ruumiinosia, kuten huulia, silmiä ja rintoja, kokonaisuudestaan irrotettuina, samaan aikaan rajattuna ja paeten määrittelyä ja kontekstointia. Kuvia rinnastetaan vankilan rajoituksiin, piikkilanka-aitoihin, viestintää kontrolloiviin vierailuaikoihin ja puhelinrivistöihin. Kontrollin tarve ja siitä pakeneminen sekä naisten ruumiin yksityiskohtien

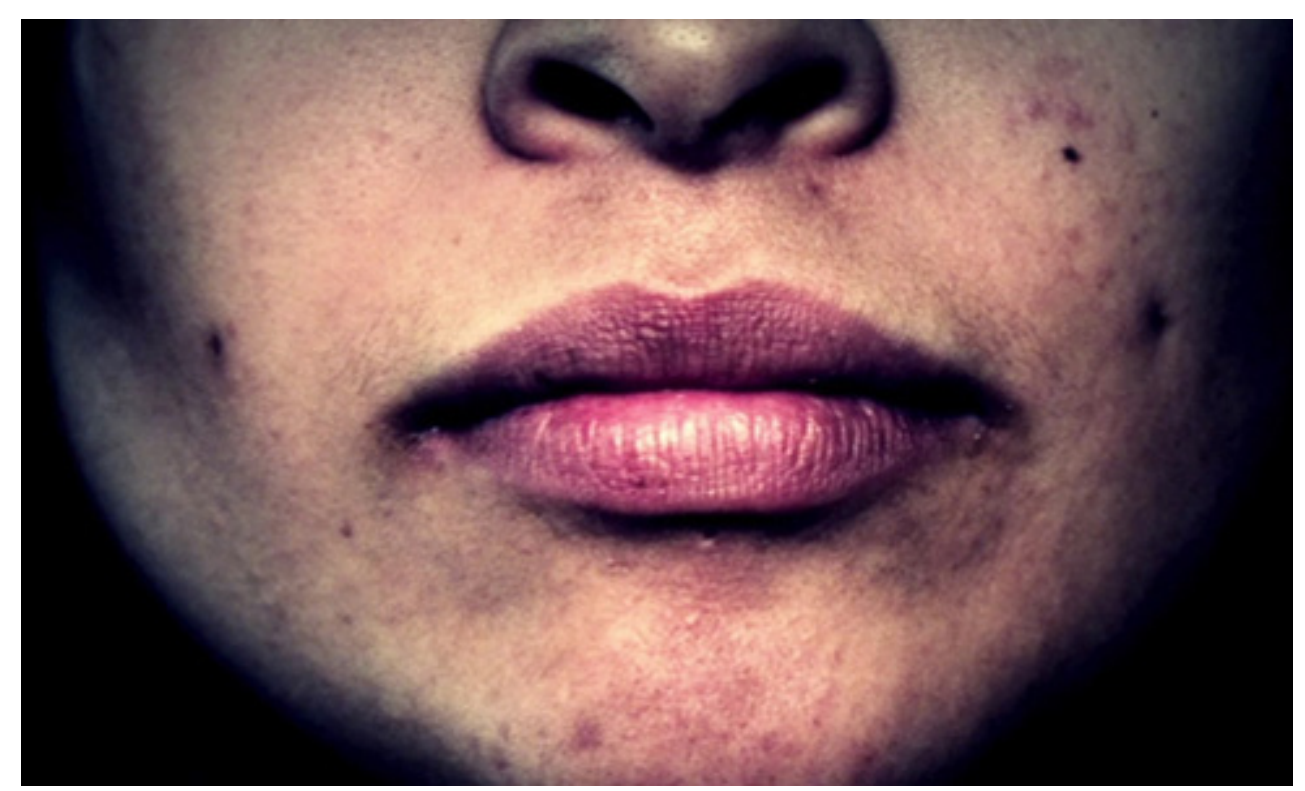

Sarjan alkutunnus koostuu naisten ruumiinosien kuvista. Kuva: kuvakaappaus. 
vaatima huomio yhdistyvät sarjan tunnukseen, Regina Spektorin säveltämään, sanoittamaan ja esittämään "You've Got Time" -kappaleeseen, jossa lauletaan vangittujen naisten äänien muistamisesta:

The animals, the animals, trapped, trapped, trapped 'till the cage is full.

[- - ] Remember all their faces, remember all their voices.

Myös sarjan ensimmäisten sekuntien myötä korostetaan ruumiillisia elementtejä. Piperin voice-over-ääni muistelee hänen lämmintä suhdettaan suihkussa käymiseen. Samalla takautumien kautta kuvataan häntä kylpemässä lapsena, tyttöystävänsä kanssa ja poikaystävän kanssa, kunnes päädytään vankilan suihkutiloihin, joissa, toisin kuin aiemmissa kuvissa, Piper arastelee alastomuuttaan. (K1:J1 "I Wasn't Ready".) Yhtäältä ratkaisu kertoo henkilökohtaisen tilan puutteesta vankilassa mutta toisaalta myös häpeilemättömästä suhtautumisesta naisen ruumiillisuuteen. Avaus luo myös sarjalle tyypillisen kuvaustavan, jossa naisen ruumis on esillä niin vaatetettuna kuin alastomanakin, niin seksuaalisena toimijana kuin arkisena olemassaolonakin.

Ensimmäisissä jaksoissa korostuvat naisten ruumiiden kontrolloimattomuus, vallattomuus ja liiallisuus groteskiuteen saakka. Vankeja kuvataan ulostamassa, hikoilemassa, kuorsaamassa, piereskelemässä, oksentamassa ja niin edelleen. Verrattuna amerikkalaisen viihdetuotannon valtavirtaiseen kauneusihanteeseen vankien kehot vaikuttavat jopa groteskeilta. Kehot, joista suurin osa on rodullistettuja, vertautuvat Piperin vaaleaan, siistiin ja kontrolloituun kehoon, joka tarjoaa turvapaikan katsojalle (Hancock 2016). Esimerkiksi latinotaustaisen Blanca Floresin (Laura Gómez) huolittelematon ulkomuoto ja taipumus puhua/huutaa itsekseen pelottavat Piperia (K1:J1 "I Wasn't Ready"). Samoin katsoja voi samaistua Piperin järkytykseen, kun hän herää keskellä yötä tummaihoisen Suzannen virtsatessa hänen sänkynsä vieressä (K1:J3, "Lesbian Request Denied"). Piperin ja katsojan sen hetkisestä näkökulmasta teko vaikuttaa käsittämättömältä, ahdistavalta ja uhkaavalta, mutta myöhemmin sarjan avatessa Suzannen ajattelumaailmaa sama tapahtuma näyttäytyy inhimillisenä kyvyttömyytenä käsitellä jatkuvaa torjutuksi tulemista.

Sarjamaisuudesta juontuva kerronnan kehittyminen on näkyvillä naisten ruumiillisuuden käsittelyssä. Kuten Danielle Hancock tuo esille, sarjan alkaessa keskittyä enemmän muihinkin vankeihin kuin Piperiin, myös rodullistettu ruumiillisuus alkaa muuttua hallitummaksi ja groteskeja elementtejä ei tuoda enää yhtä vahvasti esille. Sen sijaan arkipäiväisiä ruumiillisia toimintoja ja niiden näkyvyyttä kuvataan vankilan tuottamana pakkotilana, harvoin vankeihin liittyvänä elementtinä. (Hancock 2016.) Blanca Floresinkin irrationaalista käytöstä selitetään piilotetun puhelimen käytöllä ja henkilökohtaisen hygienian puutteet alkavat toimia jopa auktoriteetin vastustamisen muotona. Pahalle haiseminen vapauttaa hänet profiloiduista ruumiintarkistuksista ja siten ruumiillinen kurittomuus mahdollistaa hänelle pienimuotoista vallankäyttöä (K4:J9 "Turn Table Turn").

Ratkaisu tuo esille, miten sarjan representaatioissa groteskiutta etäännytetään vähitellen rodullistettujen naisten ruumiista. Siirtymistä huolimatta groteskiuteen liittyvät teemat liittyvät sarjassa useammin muihin kuin valkoisiin hahmoihin, joiden kohdalla esimerkiksi epäpuhtaus liittyy huumeriippuvuuteen. Esimerkiksi homssuinen Angie Rice (Julie Lake) identifioidaan suihkukakkaajaksi (hän salakuljettaa huumeita nielemällä), mistä siivoustyössä oleva Lorna vaatii tätä tilille yleisen säädyllisyyden vuoksi (K4: J9 "Turn Table Turn"). 
Naisten ruumiilliset prosessit, kuten ruumiintoiminnot ja ikääntyminen, näytetään ensin päällekäyvinä, naisiin kohdistettujen kauneusihanteiden vastaisina toimintoina. Yhtäältä tämä voidaan nähdä kurittomuuden prosessina, jossa naiseutta ei muokata miellyttämään miehistä katsetta. ${ }^{8}$ Tarinalinjojen kehittyessä kurittomuus kuitenkin kontekstoidaan uudella tavalla - ruumiillisuutta aletaan normalisoida osana naisten luonnollista elämää, jota vankilainstituutio on kyvytön käsittelemään. Tällä tavoin sarja osoittaa konventionaalisten naisruumiiden kuvausten rakentuneisuuden ja luo uudenlaisen normaaliuden, jossa ruumiin toiminnot eivät tee naisesta vähemmän naisellista.

Vastaava muutos tapahtuu vanhuuden käsittelyssä. Aluksi vanhukset ("golden girls") ovat lähes näkymätön ryhmä vankilayhteisössä, mutta toisella tuotantokaudella heidän yksilöllisiin tarinoihinsa kiinnitetään huomiota. Samalla ikääntymiseen eivät liity enää vain fyysiset piirteet, kuten ihon rypistyminen, vaan myös vankilamaailman kyvyttömyys hoitaa vanhuuteen liittyviä asioita, kuten terveyden ja muistin heikkenemistä. (Krainitzki 2016, 217-219.) Esimerkiksi dementiasta kärsivää Jimmy Cavanaughia (Patricia Squire) avustavat lähinnä muut vangit, ja vankilajärjestelmä vapauttaa/hylkää hänet bussiasemalle päästäkseen vastuusta (K2:J7 "Comic Sans"). Samaa kerrontaratkaisua, jossa vankila pakenee institutionaalista vastuutaan, käytetään myös mielenterveysasioissa, joissa vangit auttavat toisiaan.

Kehityslinja, jossa ruumiillista toimintaa arkipäiväistetään vankiyhteisön sisällä, ulottuu naisten seksuaalisuuden käsittelyyn. Sarjassa korostetaan naisten läheisyyden tarvetta ja seksuaalisuutta, sillä ruumiillisista suhteista muihin ihmisiin syntyy henkireikä vangitsemisen kokemukseen. Sarjassa esitetty seksuaalisuus poikkeaa - muun muassa Bad Girls -sarjan esimerkkiä mukaillen - heteronormatiivisista arvoista. Lesbosuhteet esitetään tavallisina, haluttavina ja mahdollisina, ja naisten seksuaalisuudelle annetaan eianteeksipyytelevä asenne. (Vrt. Herman 2003.) Naistoimijuuden korostaminen voidaan nähdä kurittomana käytöksenä ja vankilasarjassa toisiin naisiin kohdistuva fyysinen halu ja sen ruumiillinen esilletuonti totuttuja valtarakenteita horjuttavana käytöksenä. Esimerkiksi Alyson Millerin mukaan naisen halu nähdään patriarkaalisessa yhteiskunnassa vaikeasti hallittavana ja ennaltaarvaamattomana. Tästä syystä myös naisten seksuaalisuuden representaatio on tyypillisesti kaksijakoista: naisen seksuaalisuus on samaan aikaa kiehtovaa ja uhkaavaa. Monet kertomukset heijastavatkin kulttuurista tarvetta rajoittaa naisten kuritonta seksuaalisuutta sekä esteettisesti että moraalisesti ja pyrkiä saamaan naisen halu kategorioiduksi esimerkiksi avioliiton kautta. (Miller 2013, 368, 380.)

Orange Is the New Blackissa seksuaalisuus ja seksuaaliset aktit tuodaan näyttävästi televisioruuduille. Patriarkaalista moraalikoodistoa haastavaa ratkaisua verrataan sarjan sisällä sosiaalityöntekijä Healyn konservatiivisiin näkemyksiin naisista ja naisen paikasta. Hän varoittaa uusia naisvankeja, mukaan lukien Piperia, lesbouden vaaroista ja on aggressiivisen ahdistunut, kun Piper osoittaa seksuaalista kiinnostusta entistä tyttöystäväänsä Alexia kohtaan. Healyn asenne edustaa vanhentunutta, joskin edelleen olemassa olevaa näkemystä naisten kurittomuuden ja moraalin suhteista.

Rikos ja synti toimivat synonyymeinä koloniaalisen ajan Yhdysvalloissa, jolloin naisten rikollisuutta määrittelivät epänormatiivinen seksuaalisuus ja noituudeksi tulkitut teot. Rikollisuus määrittyi epäjärjestyksenä ja tottelemattomuutena yhteisöissä, joissa painottuivat uskonnon, puritaanisen elämäntavan ja sosiaalisen hierarkian merkitys. Yhteiskunnan modernisoituessa
8 Laura Mulveyn (1986) klassikkoteorian mukaan elokuvien konventionaalinen kuvaus asemoi katsojan miehen katseeseen ja olettaa kaikkien katsojien nauttivan miehen katseesta. Teoriaa on kritisoitu muun muassa siitä, että se aliarvioi naisten mielihyvää katsomiskokemuksessa (esim. Manlove 2007, 88-91), mutta kritiikistä huolimatta teoria on säilyttänyt asemansa merkittävänä feministisenä elokuvateoriana. 
amerikkalainen moraalikoodisto muuttui, ja rikosten määrittely on siirtynyt moraalikysymyksistä omaisuus-, huume- ja väkivaltarikoksiin. Tämä on näkynyt erityisesti seksiin liittyvien säännösten purkamisessa 1960-luvulta eteenpäin, kun pornografia, homoseksuaalisuus ja avioliiton ulkopuoliset suhteet on vapautettu rikossyytteistä. (Friedman 1993.) Moraaliset kerrostumat ovat kuitenkin edelleen olemassa, ja Orange is the New Blackissä ne ovat läsnä vankilan käytössäännöissä, kuten (homo)seksuaalisuuden tuomitsemisessa. Naisten seksuaalisia suhteita pyritään kontrolloimaan, ja esimerkiksi Healyn asenne leimaa lesbosuhteet syntisiksi, rappiollisiksi ja miesten seksuaalisuutta uhkaaviksi. Vankien näkökulma puolestaan kyseenalaistaa Healyn (ja sitä kautta yhteiskunnan) konservatiivista asennetta.

Naisten suhteet eivät myöskään asettaudu yksiselitteisesti hetero/homo/ biseksuaalisuus-kategorioihin, vaan monet hahmot, Piper mukaan lukien, etsivät seksuaalisuuttaan ja läheisyyden kokemusta saatavilla olevista vaihtoehdoista. Esimerkiksi Lornan ja Nickyn välinen lesbosuhde on toisinaan katkolla Lornan sulhas-/perhefantasioiden takia. Erityisesti valkoisiksi tunnistettavien hahmojen seksuaaliset suhteet ovat vaihtelevia, kun puolestaan muilla tavoilla rodullistettujen hahmojen seksuaalisuutta ei käsitellä yhtä avoimesti. Suzanne ja Poussey (Samira Wiley) identifioituvat lesboiksi, ja Dayalla (Dascha Polanco) on suhde miespuoliseen vanginvartijaan, mutta monien tummaihoisten ja latinoiden seksuaalisuuteen liittyviä tarpeita ei nosteta vahvasti esille tai liu'uteta. Rodullistettua seksuaalista mielihyvää myös piilotetaan sarjassa: Suzanne ja Poussey usein pettyvät seksuaalisen täyttymyksen saralla (esimerkiksi Pousseyn vankilasuhteissa korostuvat ystävyys ja ihastuminen), ja Dayan suhde johtaa pakotettuun seksiin toisen vanginvartijan kanssa. Rodullistetun mielihyvän esittämiseen liittyvien ongelmien vastapainoksi sarjan kerronnan kehittymisessä on panostettu rotujenvälisiin suhteisiin ja niiden avoimeen hyväksyntään kuvatussa vankilayhteisössä.

Kokonaisuutena Orange Is the New Black esittää naisten ruumiit läsnä olevina, anteeksipyytelemättöminä ja ylpeinä omasta toimijuudestaan - oli se sitten seksuaalista tai muuta ruumiillista toimijuutta. Olennaista sarjassa on prosessimaisuus, jossa ensin ruumiillinen toimijuus pakotetaan katsojan katseen kohteeksi varoittamatta ja sellaisenaan korostaen liiallisuutta, ylitsevuotavuutta ja vallattomuutta. Vähitellen toimijuus normalisoidaan osaksi naisten elämää, ja se kontekstoidaan osaksi vankilan luomaa rajattua yksityisyyden käsitystä. Astuttuaan ensin naisen kunniallisen keskiluokkaisen heteronormatiivisen paikan ulkopuolelle sarjan naiset asemoivat itsensä uudelleen.

\section{Lopuksi}

Kaiken kaikkiaan vangit ovat omien elämiensä sankareita, vaikkakaan heidän elämänsä eivät ole täydellisiä tai lainmukaisia. Tällä tavoin Orange Is the New Black esittää naiset osallisina sukupuolittavien normien purkamiseen. He haluavat olla jotain, olla tunnistettavia, saada huomiota ja tulla merkittäviksi. Heidän rikoksiinsa liittyy kiehtovuuden ja kapinallisuuden merkityksiä tai vahvoja inhimillisiä tunteita, kuten rakkautta, katkeruutta tai turhautumista. Naisten halu olla tunnistettavia ja osallisia johtaa toimintaan, joka hyökkää yhteiskunnan järjestystä vastaan kyseenalaistaen normeja ja sääntöjä (vrt. Presdee 2000, 4-6, 18-19).

Intiimissä ja suljetussa vankilatilassa naiset myös kannustavat toisiaan olemaan ylpeitä kurittomuudestaan. Vankilan urapäivässä osa vangeista toimii 
malleina "dress for success" -näytöksessä. Vangit ovat saaneet valita, miten he pukeutuisivat työhaastatteluun, ja lavalla urapäivän vetäjä kommentoi heidän asuvalintojaan normatiivisella business-koodistolla, jonka mukaisesti harva naisista on pukeutunut. Vetäjä kritisoi valintoja sopimattomina, liian villeinä, ei-konventionaalisina tai liian seksikkäinä. Nicky vastaa saamaansa arvosteluun: "Sorry, it is not uptight and boring", ja saa aplodit kanssavangeiltaan. (K2:J2 "Looks Blue, Tastes Red".)

Lainaus tiivistää sarjan asenteen naisen paikasta. Koomisen kehystämisen kautta sarja keskustelee monien olemassa olevien sosiaalisten oletusten kanssa siitä, millaisia ovat hyväksyttävät asenteet, arvot ja käytökset naisille. Pilkkaamalla näitä normeja sarja kyseenalaistaa patriarkaalisen yhteiskunnan taustaoletukset sijoittamalla naiset, joista katsojat ovat suurelta osin oppineet pitämään, naisen perinteisen paikan, heteroseksuaalisuuden ja valkoisuutta, nuoruutta ja hoikkuutta korostavien kauneusihanteiden ulkopuolelle. Yhtäältä kerronta perustuu sukupuolittuneeseen näkökulmaan maailmasta, jossa naiseus ja erityisesti ei-valkoiseksi rodullistettu tai esteettisesti kauneusihanteista poikkeava naiseus on toiseutta. Sarja leikittelee jatkuvasti naisten ruumiiden ja käyttäytymisen skandaalimaisuudella, mutta samaan aikaan se purkaa oletettuja skandaalin aiheita normalisoimalla erilaisia naiseuksia, vaikkakin tässä suhteessa valkoisiksi tunnistetuilla on sarjassa enemmän liikkumavaraa kuin muilla tavoin rodullistetuilla hahmoilla.

Kahden vastakkaisen näkökulman yhtäaikainen läsnäolo mahdollistuu sarjallisuuden ja muuntuvien kerronnan näkökulmien avulla. Kerronnan jatkuvuuden kautta naisista tulee aktiivisia toimijoita, jotka kieltäytyvät uhrin asemasta ja myöntävät tavoittelevansa itsekkäästi omaa etuaan ilman, että astuvat hoivaajan tai muista riippuvaisen rooliin. Naisyhteisön jäsenet eivät pyytele anteeksi olemassaoloaan, ja juuri tämän takia he ovat ulkomaailman silmissä kurittomia. Vankilakuvaus mahdollistaa kurittomuuden muutosvoimaa, mutta samalla se on kuvattu rankaisevana tilana, johon yhteiskunta on eristänyt sukupuolittuneita rajoja muuttavat ja murtavat naiset.

\section{Tutkimuskirjallisuus}

Arnold, Sarah (2014) “Ghettoising the 'Strong Female Lead' - Netflix, Demographics and Gendered Categorisation". CST Online 4.7.2014. Saatavilla: <http://cstonline.tv/ghettoisingthe-strong-female-lead> (linkki tarkistettu 15.6.2016).

Auletta, Ken (2014) "Annals of Communication. Outside the Box: Netflix and the Future of Television". The New Yorker 3.2.2014. Saatavilla: <http://www.newyorker.com/magazine/2014/02/03/ outside-the-box-2> (linkki tarkistettu 15.6.2016).

Bal, Mieke (1999) Narratology. Introduction to the Theory of Narrative. Toinen painos. Toronto, Buffalo, Lontoo: University of Toronto Press.

Ball, Vicky (2013) “Forgotten Sisters: The British Female Ensemble Drama”. Screen 54:2, 244-248.

Barak, Gregg; Leighton, Paul \& Cotton, Allison (2015) Class, Race, Gender, and Crime: The Social Realities of Justice in America. Lontoo: Rowman \& Littlefield.

Butler, Judith (1999) Gender Trouble: Feminism and the Subversion of Identity. New York, Lontoo: Routledge.

Bynum, Victoria E. (1992) The Politics of Social and Sexual Control in the Old South. Chapel Hill: The University of South Carolina Press.

Caputi, Jane (2015) “The Color Orange? Social Justice Issues in the First Season of Orange Is the New Black". The Journal of Popular Culture 48:6, 1130-1150. 
Carson, E. Ann (2015) Prisoners in 2014. U.S. Department of Justice: Bureau of Justice Statistics, $<$ http://www.bjs.gov/index.cfm?ty=pbdetail\&iid=5387> (linkki tarkistettu 12.10.2016).

Cawelti, John G. (1975) “Myths of Violence in American Popular Culture". Critical Inquiry 1:3, 521-541.

Cecil, Dawn K. (2015) Prison Life in Popular Culture: From the Big House to Orange is the New Black. Boulder, CO: Lynne Rienner.

Collins, P. H. (2009) Black Feminist Thought: Knowledge, Consciousness, and the Politics of

Empowerment. Kolmas painos. New York, NY: Routledge.

Dhamoon, Rita Kaur (2011) "Considerations on Mainstreaming Intersectionality". Political Research Quarterly 64:1, 230-243.

Enck, Suzanne M. \& Morrissey, Megan E. (2015) “If Orange Is the New Black, I Must Be Color Blind: Comic Framings of Post-Racism in the Prison-Industrial Complex". Critical Studies in Media Communication 32:5, 303-317.

Faith, Karlene (2011 [1993]) Unruly Women: The Politics of Confinement E Resistance. New York: Seven Stories Press.

Friedman, Lawrence M. (1993) Crime and Punishment in American History. New York: BasicBooks.

Glaze, Lauren; Kaeble, Danielle \& Minton, Todd (2015) Correctional Populations in the United States, 2014. U.S. Department of Justice: Bureau of Justice Statistics, <http://www.bjs.gov/index. cfm?ty=pbdetail\&iid=5519> (linkki tarkistettu 15.6.2016).

Gordon, Bonnie (2004) Monteverdi's Unruly Women: The Power of Song in Early Modern Italy. Cambridge: Cambridge University Press.

Griffin, Rachel Alicia (2014) "Pushing into Precious: Black Women, Media Representation, and the Glare of the White Supremacist Capitalist Patriarchal Gaze". Critical Studies in Media Communication 31:3, 182-197.

Hancock, Danielle (2016) “'Give it a Week, You'll be Pissing and Farting with the Rest of Us': Becoming Grotesque in Orange is the New Black". CST Online 17.3.2016, <http://cstonline.tv/ oitnb> (linkki tarkistettu 15.6.2016).

Herman, Didi (2003) “'Bad Girls Changed My Life' Homonormativity in a Women's Prison Drama". Critical Studies in Media Communication 20:2, 141-159.

hooks, b. (1992) Black Looks: Race and Representation. Boston, MA: South End Press.

Horstkott, Silke (2009) “Seeing or Speaking: Visual Narratology and Focalization, Literature to Film". Teoksessa Sandra Heinen \& Roy Sommer (toim.) Narratology in the Age of Cross-Disciplinary Narrative Research. Berliini \& New York: Walter de Gruyter, 170-192.

Jarvis, Brian (2013 [2006]) “The Violence of Images: Inside the Prison TV Drama Oz”. Teoksessa Paul Mason (toim.) Captured by the Media: Prison Discourse in Popular Culture. Routledge: New York, 154-171.

Krainitzki, Eva (2016) “'You've Got Time'. Ageing and Queer Temporality in Orange is the New Black". Teoksessa Maricel Oró-Piqueras \& Anita Wohlmann (toim.) Serializing Age: Aging and Old Age in TV Series. Bielefeld: Transcript Verlag, 207-232.

Manlove, Clifford T. (2007) “Visual ‘Drive' and Cinematic Narrative: Reading Gaze Theory in Lacan, Hitchcock, and Mulvey". Cinema Journal 46: 3, 83-108.

Matrix, Sidneyeve (2014) “The Netflix Effect: Teens, Binge Watching, and On-Demand Digital Media Trends". Jeunesse: Young People, Texts, Cultures 6:1, 119-138.

McKay, Jade (2006) "Narrativising the 'Woman Monster': Heroines who Transgress the Feminine Script". Quest 2006/2. Saatavilla: <http://www.qub.ac.uk/sites/QUEST/FileStore/ Filetoupload,52369,en.pdf> (linkki tarkistettu 15.6.2016).

Miller, Alyson (2013) "Scandalous Women: Gender and Identity in Top-notch Smut". Journal of Gender Studies 22:4, 367-382.

Mulvey, Laura (1986 [1975]) “Visual Pleasure and Narrative Cinema”. Teoksessa Philip Rosen (toim.) Narrative, Apparatus, Ideology. A Film Theory Reader. New York: Columbia University Press, 198-209.

Najumi, Mohadesa (2013) "College Feminisms: A Critical Analysis of Orange Is the New Black: The Appropriation of Women of Color". The Feminist Wire 28.8.2013. Saatavilla: <http://www. thefeministwire.com/2013/08/a-critical-analysis-of-orange-is-the-new-black-the-appropriationof-women-of-color/> (linkki tarkistettu 15.6.2016). 
Niederhoff, Burkhard (2011) "Focalization". Teoksessa Peter Hühn \& al. (toim.) The Living Handbook of Narratology. Hamburg: Hamburg University Press. Saatavilla: <http://wikis.sub. uni-hamburg.de/lhn/index.php/Focalization> (linkki tarkistettu 15.3.2013).

Presdee, Mike (2000) Cultural Criminology and the Carnival of Crime. Lontoo, New York: Routledge.

Renzetti, Claire M; Goodstein, Lynne \& Miller, Susan L. (toim.) (2006) Rethinking Gender, Crime, and Justice: Feminist Readings. Oxford: Oxford University Press.

Rowe, Kathleen (1995) The Unruly Woman: Gender and the Genres of Laughter. Austin: University of Texas Press.

Shackelford, Ashleigh (2016) "Orange is the New Black is Trauma Porn Written for White People". Wear Your Voice. Intersectional Feminist Media 20.6.2016. Saatavilla: <http://wearyourvoicemag.com/more/entertainment/orange-is-the-new-black-trauma-porn-written-whitepeople> (linkki tarkistettu 25.9.2016).

Shimpach, Shawn (2015) "The Metrics, Reloaded". Teoksessa Toby Miller (toim.) The Routledge Companion to Global Popular Culture. New York, Lontoo: Routledge, 93-103.

The Feminist Griote 19.8.2013. Orange is NOT the New Black. Saatavilla: <http://thefeministgriote. com/orange-is-not-the-new-black> (linkki tarkistettu 15.6.2016).

Vänskä, Annamari (2006) Vikuroivia vilkaisuja. Ruumis, sukupuoli, seksuaalisuus ja visuaalisen kulttuurin tutkimus. Taidehistoriallisia tutkimuksia - Konsthistoriska studier 35. Helsinki: Taidehistorian seura - Förening för konsthistoria,

Walker, Samuel; Spohn, Cassia \& DeLone, Miriam (2012) The Color of Justice: Race, Ethnicity, and Crime in America. Belmont: Wadsworth.

Walmsley, Roy (2015). World Female Imprisonment List. Kolmas painos. Institute for Criminal Policy Research. Saatavilla: <http://www.prisonstudies.org/sites/default/files/resources/downloads/world_female_imprisonment_list_third_edition_0.pdf > (linkki tarkistettu 3.9.2016).

Walmsley, Roy (2016) World Prison Population List. 11. painos. Institute for Criminal Policy Research. Saatavilla: <http://www.prisonstudies.org/sites/default/files/resources/downloads/ world_prison_population_list_11th_edition.pdf> (linkki tarkistettu 3.9.2016).

Welsh, Andrew; Fleming, Thomas \& Dowler, Kenneth (2011) “Constructing Crime and Justice on Film: Meaning and Message in Cinema". Contemporary Justice Review 14:4, 457-476. 